\title{
Pengaruh Penambahan Probiotik dalam Pakan terhadap Pertambahan Berat Badan, Konsumsi Pakan dan Konversi Pakan Ayam Broiler
}

\author{
Yovita F. Seran ${ }^{\mathrm{a}}$, Charles V. Lisnahan ${ }^{\mathrm{b}}$ dan Theresia I. Purwantiningsih ${ }^{\mathrm{c}}$ \\ ${ }^{a}$ Fakultas Pertanian, Universitas Timor, Kefamenanu, TTU - NTT, Indonesia, email: yovitafloridaseran07@ gmail.com \\ ${ }^{b}$ Fakultas Pertanian, Universitas Timor, Kefamenanu, TTU - NTT, Indonesia,email: charleslisnahan@yahoo.co.id \\ ${ }^{c}$ Fakultas Pertanian, Universitas Timor, Kefamenanu, TTU - NTT, Indonesia, email: theresiaicha@gmail.com
}

\section{Article Info}

\section{Article history:}

Received 31 Januari 2019

Received in revised form 17 Maret 2019 Accepted 21 April 2019

DOI:

Keywords :

Ayam Broiler

Probiotik

Pertambahan Berat Badan

Konsumsi Pakan

Konversi Pakan https://doi.org/10.32938/ja.v4i2.647

\begin{abstract}
Abstrak
Penelitian ini bertujuan untuk mengetahui pengaruh penambahan probiotik dalam pakan terhadap pertambahan berat badan, konsumsi pakan, dan konversi pakan ayam broiler. Penelitian ini telah dilaksanakan di kandang Program Studi Peternakan, Fakultas Pertanian, Universitas Timor sejak bulan September sampai November 2018. Ternak yang digunakan adalah ayam broiler berumur 1 hari berjumlah 80 ekor. Pakan yang digunakan adalah $\mathrm{BR}_{1}, \mathrm{BR}_{2}$ dan probiotik. Metode yang digunakan adalah Rancangan Acak Lengkap (RAL) yang terdiri dari 4 perlakuan dan4 ulangan. Perlakuan yang diberikan masing-masing: $\mathrm{P}_{0}=$ pakan komersial tanpa probiotik, $\mathrm{P}_{1}=99,7 \%$ pakan komersial $+0,3 \%$ probiotik, $P_{2}=99,5 \%$ pakan komersial $+0,5 \%$ probiotik, $P_{3}=99,3 \%$ pakan komersial $+0,7 \%$ probiotik. Variabel yang diamati adalah pertambahan berat badan, konsumsi pakan, dan konversi pakan. Data pertambahan berat badan masing-masing $\mathrm{P}_{0} \mathrm{P}_{1} \mathrm{P}_{2}$ dan $\mathrm{P}_{3}$ adalah 49,05; 52,53; 48,8 dan 53,42 g/ekor/hari. Konsumsi pakan 134,74; 137,21; 138,16 dan 139,52 g/ekor/hari. Konversi pakan 2,$75 ; 2,62 ; 2,83$ dan 2,61. Analisis statistik menunjukkan bahwa penambahan probiotik berpengaruh sangat nyata $(\mathrm{P}<0,01)$ terhadap konsumsi pakan, sedangkan pada pertambahan berat badan dan konversi pakan berpengaruh tidak nyata. Disimpulkan bahwa penambahan probiotik dalam pakan tidak berpengaruh terhadap pertambahan berat badan, konversi pakan tetapi dapat berpengaruh nyata terhadap konsumsi pakan.
\end{abstract}

\section{Pendahuluan}

Peternakan ayam pedaging (ayam broiler) di Kabupaten Timor Tengag Utara jumlahnya semakin meningkat. Peningkatan ni sebagai bagian dar penyediaan protein yang dibutuhkan masyarakat karena meningkatnya kesadaran masyarakat tentang pentingnya gizi bagi masyarakat semakin meningkat, menyebabkan peternak berusaha semaksimal mungkin memacu pertumbuhan atau produksinya. Banyak faktor yang menentuka produktivitas ayam broiler seperti perkandangan, pencegahan penyakin dan pakan. Pakan yang diberikan harus memenuhi keseimbangan protein dan energi serta keseimbangan makro maupun mikro nutrient.

Pakan yang lengkap dan seimbang nutrientnya menyebabkan jumlah nutrient yang tercerna dan terabsorbsi lebih banyak sehingga yang terbuang lewat ekskreta menjadi minim. Salah satu faktor yang berpengaruh terhadap jumlah pakan yang tercerna dan terabsorbsi lebih baik adalah kondisi dari saluran pencernaan terutama pada bagian usus. Probiotik merupakan bahan tambahan berupa mikroba hidup baik bakteri maupun kapang yang mempunyai pengaruh menguntungkan pada hewan inang dengan meningkatkan mikroba dalam saluarn pencernaan. Mikroba hidup akan menghalang bakteri yang bersifat negatif sehingga dapat menguntungkan pertumbuhan yang sifatnya positif (Sumardi, 2008). Pakan yang dikonsumsi dapat dimaksimalkan penyerapan nutrientnya. Hipotesis pada penelitian ini adalah penambahan probiotik dalam pakan dapat meningkatkan konsumsi pakan, pertambahan berat badan, dan menurunkan konversi pakan ayam broiler. Pertambahan berat badan mempunyai definisi yang sangat sederhana yaitu peningkatan ukuran tubuh. Pertambahan bobot badan juga dapat diartikan sebagai perubahan ukuran yang meliputi pertambahan bobot hidup, bentuk dimensi liniear dan komposisi tubuh termasuk komponen-komponen tubuh seperti otak, lemak, tulang, dan organ-organ serta komponen-komponen kimia terutama air pada karkas, Pertambahan bobot badan diperoleh melalui pengukuran kenaikan bobot badan dengan melakukan penimbangan dalam tiap minggu (Soeparno, 2005). Ayam mengkonsumsi pakan untuk memenuhi kebutuhan energinya. Sebelum kebutuhan energinya terpenuh ayam akan terus makan (Kartasudjana dan Suprijanta, 2006). Jika ayam diberi pakan dengan kandungan energi yang rendah maka ayam akan makan lebih banyak. Sebaliknya jika disediakan ransum dengan kandungan energi yan tinggi maka ayam akan makan lebih sedikit karena kebutuhan energinya cepat terpenuhi. Temperatur lingkungan berpengaruh terhadap konsumsi pakan. Konversi pakan (feed conversion ratio) adalah perbandingan antara jumlah pakan yang dikonsumsi oleh ayam dengan pertambahan bobot badan yang diperoleh selama waktu tertentu. Apabila nilai yang didapat semakin kecil artinya ternak semakin efisien dalam mengkonsumsi pakan yang diberikan. Kemampuan ayam pedaging mengubah pakan menjadi berat hidup lebih cepat dibandingkan ayam kampung. Penelitian ini bertujuan untuk mengetahui pengaruh penambahan probiotik terhadap pertambahan berat badan, konsumsi pakan dan konversi pakan ayam broiler.

\section{Metode}

\subsection{Waktu dan lokasi penelitian}

Penelitian ini dilaksanakan di kandang Program Studi Peternakan, Fakultas Pertanian, Universitas Timor. Penelitian berlangsung selama 1 periode produksi (45 hari), terhitung dari bulan September sampai November tahun 2018.

\subsection{Alat dan bahan}

Peralatan yang digunakan adalah timbangan duduk kapasitas $5 \mathrm{~kg}$ dengan tingkat kepekaan $1 \mathrm{~g}$ untuk menimbang ternak dan timbangan merek OHAUS untuk menimbang pakan, tempat makan, tempat minum, pemanas (lampu), peralatan pembersih dan alat tulis menulis. Bahan yang digunakan yaitu pakan $\mathrm{BR}_{1}$ dan $\mathrm{BR}_{2}$, DOC (Day Old Chick) ayam broiler 100 ekor, dan bahan pakan tambahan berupa probiotik

\subsection{Rancangan Penelitian}

Penelitian ini menggunakan Rancangan Acak Lengkap (RAL) yang terdiri dari 4 perlakuan dan 4 ulangan. Masing-masing unit percobaan terdapat 5 ekor broiler yang penempatannya dilakukan secara acak, dengan perlakuannya sebagai berikut : $\mathrm{P}_{0}$ : Pakan komersial tanpa probiotik (Kontrol), $\mathrm{P}_{1}: 99,7 \%$ pakan komersial $+0,3 \%$ probiotik, $\mathrm{P}_{2}: 99,5 \%$ pakan komersial + $0,5 \%$ probiotik, $\mathrm{P}_{3}: 99,3 \%$ pakan komersial $+0,7 \%$ probiotik. Pemberian pakan perlakuan dalam bentuk tepung

\subsection{Prosedur Penelitian}

Beberapa tahapan yang dilakukan dalam penelitian meliputi persiapan kandang sampai pada penempatan liter.Alat Kandang yang digunakan adalah kandang litter yang dibuat dalam 16 petak. Tiap blok terdiri dari 4 petak kandang berukuran $1 \mathrm{~m} \times 0,5 \mathrm{~m}$, tinggi dinding kandang $50 \mathrm{~cm}$ dan tinggi alas $20 \mathrm{~cm}$. Kemudian seluruh ruang kandang serta peralatan makan minum dicucihamakan dengan antiseptik (neo antisep) seminggu sebelum penelitian. Setelah DOC tiba, tindakan selanjutnya adalah : DOC diistrahatkan kurang lebih $1 / 2$ jam dan selanjutnya pemberian air gula dengan tujuan untuk memberikan energi pada DOC, pemberian pakan awal dengan tujuan adaptasi (selama 10 hari), pemberian air minum dicampur vitachick. Pada umur 4 hari dilakukan vaksinasi $\mathrm{ND}_{1}$ melaluli tetes mata. Data berupa pertambahan berat badan, konsumsi pakan dan konversi pakan diambil pada minggu terakhir sebelum panen.

\subsection{Analisis Data}

Data yang diperoleh dianalisis menggunakan analisis sidik ragam (Anova) berdasarkan Rancangan Acak Lengkap dan dilanjutkan dengan uji jarak berganda Duncan (Duncan's New Multiple Range Test) untuk melihat perbedaan (Steel dan Torrie, 1991).

\section{Hasil dan Pembahasan}

\subsection{Pengaruh Perlakuan Terhadap Pertambahan Berat Badan}

Pertumbuhan umumnya dinyatakan dengan pengukuran kenaikan bobot badan yang dengan mudah dilakukan dengan penimbangan berulang-ulang dan diketengahkan dengan pertumbuhan badan tiap hari, tiap minggu, atau tiap waktu lainya (Tillman et al., 1986). Pertambahan berat badan adalah selisih antara berat badan akhir dengan berat badan awal dibagi total hari penelitian (g/ekor/hari). Pengaruh pemberian probiotik dalam pakan dengan level yang berbeda terhadap rata-rata pertambahan berat badan ayam broiler terlihat pada Tabel 1

Tabel 1. Rata-rata pertambahan berat badan ayam broiler (g/ekor/hari)

\begin{tabular}{cccccl}
\hline \multirow{2}{*}{ Ulangan } & \multicolumn{5}{c}{ Perlakuan } \\
\cline { 2 - 5 } & $\mathrm{P}_{0}$ & $\mathrm{P}_{1}$ & $\mathrm{P}_{2}$ & $\mathrm{P}_{3}$ & \\
\hline 1 & 52,05 & 55,43 & 48,78 & 58,63 & \\
2 & 46,57 & 52,83 & 49,34 & 50,64 & \\
3 & 50,64 & 47,07 & 50,17 & 52,75 & \\
4 & 46,95 & 54,79 & 46,90 & 51,65 & \\
Jumlah & 196,22 & 210,13 & 195,19 & 213,68 & 815,23 \\
Rerata & 49,05 & 52,53 & 48,80 & 53,42 & 50,95 \\
\hline
\end{tabular}

Pada Tabel 1 terlihat bahwa rata-rata pertambahan berat badan ayam broiler yang mengkonsumsi pakan dengan penambahan probiotik rata-rata keseluruhan 50,95 g/ekor sedangkan rata-rata tertinggi ditunjukkan pada perlakuan probiotik $0,7 \%$ yaitu 53,42 g/ekor dan terendah adalah perlakuan probiotik $0,5 \%$ yaitu 48,80 g/ekor dan yang terendah adalah $\mathrm{P}_{2}$ yaitu 48,80 g/ekor. Hasil uji Duncan menunjukkan bahwa antara perlakuan probiotik 
kontrol, $0,3,0,5,0,7 \%$ berbeda tidak nyata. Hal ini menunjukkan bahwa pemberian probiotik dari level $0,3 \%$ sampai $0,7 \%$ tidak mempengaruhi pertambahan berat badan ayam broiler.

Pertambahan bobot badan dipengaruhi oleh jumlah konsumsi ransum yang dikonsumsi oleh broiler (Ichwan, 2004). Diperkuat oleh Siregar (1980) bahwa pertambahan bobot badan dipengaruhi oleh jumlah ransum yang dikonsumsi, semakin tinggi tingkat konsumsi ransum, semakin tinggi pula pertambahan bobot badan yang dihasilkan dan sebaliknya semakin rendah konsumsi maka semakin rendah pula pertambahan bobot badan.

\subsection{Pengaruh Perlakuan Terhadap Konsumsi Pakan}

Konsumsi pakan adalah selisih antara jumlah pakan yang diberikan dikurangi pakan yang tidak dikonsumsi dibagi jumlah lama penelitian (gram/ekor/hari). Pengaruh pemberian probiotik dalam pakan dengan level berbeda terhadap rata-rata konsumsi pakan ayam broiler terlihat pada Tabel 2 .

Tabel 2. Rata-rata Konsumsi Pakan Ayam Broiler (g/ekor/hari)

\begin{tabular}{|c|c|c|c|c|c|}
\hline \multirow{2}{*}{ Ulangan } & \multicolumn{4}{|c|}{ Perlakuan } & \\
\hline & $\mathrm{P}_{0}$ & $\mathrm{P}_{1}$ & $\mathrm{P}_{2}$ & $\mathrm{P}_{3}$ & \\
\hline 1 & 136,01 & 136,56 & 137,30 & 139,85 & \\
\hline 2 & 134,55 & 137,55 & 138,00 & 141,84 & \\
\hline 3 & 134,64 & 138,57 & 138,49 & 135,66 & \\
\hline 4 & 133,75 & 136,14 & 138,83 & 140,73 & \\
\hline Jumlah & 538,94 & 548,82 & 552,63 & 558,08 & 2198,48 \\
\hline Rerata & $134,74^{\mathrm{b}}$ & $137,21^{\mathrm{a}}$ & $138,16^{\mathrm{a}}$ & $139,52^{\mathrm{a}}$ & 137,40 \\
\hline
\end{tabular}

Hasil analisis statistic menunjukkan bahwa perlakuan berpengaruh sangat nyata terhadap konsumsi pakan ayam broiler $(\mathrm{P}<0,01)$. Penambahan probiotik dalam pakan meningkatkan konsumsi pakan. Akan tetapi peningkatan level probiotik dari $0,3 \%-0,7 \%$, tidak memberikan efek terhadap peningkatan konsumsi pakan. Terlihat pada Tabel 2 bahwa konsumsi pakan pada perlakuan yang ditambahkan dengan probiotik $\left(\mathrm{P}_{3}, \mathrm{P}_{2}\right.$ dan $\left.\mathrm{P}_{1}\right)$ meningkat dibanding perlakuan tanpa probiotik $\left(\mathrm{P}_{0}\right)$. Konsumsi pakan tertinggi pada $\mathrm{P}_{3}(139,52$ g/ekor/hari), diikuti $\mathrm{P}_{2}\left(138,16\right.$ g/ekor/hari), $\mathrm{P}_{1} \quad(137,21 \mathrm{~g} / \mathrm{ekor} / \mathrm{hari})$ dan terendah $\mathrm{P}_{0}(134,74 \mathrm{~g} /$ ekor/hari). Penambahan probiotik $0,3 \%$ dalam pakan meningkatkan konsumsi pakan $1,83 \%$. Pada peningkatan level probiotik $0,5 \%$ dalam pakan meningkatkan konsumsi pakan 2,53\% dibanding pakan tanpa probio. Konsumsi pakan lebih tinggi lagi apabila level probiotik ditingkatkan menjadi $0,7 \%$. Pada level ini konsumsi pakan meningkat $0,98 \%$ dibanding pakan dengan level probiotik $0,5 \%$. Hal ini sejalan dengan penelitian Ridho (2015) yang menyatakan bahwa banyaknya strain mikroorganisme yang menguntungkan di dalam sekum, menyebabkan penyerapan zat-zat makanan yang terkandung di dalam pakan lebih efisien dan akan mengurangi zat-zat nutrien yang terbuang akibat dari adanya populasi mikroorganisme yang merugikan, sehingga berpengaruh pada konsumsi pakan. Konsumsi pakan ayam pedaging dipengaruhi oleh faktor seperti besar ukuran tubuh, keaktifan, temperatur, kualitas dan kuantitas pakan yang diberikan. Selain itu konsumsi pakan dipengaruhi oleh bentuk pakan, pemberian pakan dalam bentuk pellet dapat meningkatkan konsumsi pakan (Parakkasi, 1990).

\subsection{Pengaruh Perlakuan Terhadap Konversi Pakan}

Konversi pakan atau Feed Conversion Ratio adalah perbandingan antara jumlah konsumsi pakan dan pertambahan bobot badan atau dinyatakan sebagai efisiensi pakan yaitu perbandingan bobot badan per unit konsumsi pakan. Konversi pakan terbaik adalah jika nilai terendah. Konversi pakan ayam broiler terlihat pada Tabel 3 .

Tabel 3. Rata-rata Konversi Pakan Ayam Broiler (g/ekor/hari)

\begin{tabular}{cccccc}
\hline \multirow{2}{*}{ Ulangan } & \multicolumn{5}{c}{ Perlakuan } \\
\cline { 2 - 5 } & $\mathrm{P}_{0}$ & $\mathrm{P}_{1}$ & $\mathrm{P}_{2}$ & $\mathrm{P}_{3}$ & \\
& 2,61 & 2,46 & 2,81 & 2,38 & \\
2 & 2,89 & 2,60 & 2,80 & 2,80 & \\
3 & 2,66 & 2,94 & 2,76 & 2,57 & \\
4 & 2,85 & 2,48 & 2,96 & 2,72 & \\
Jumlah & 11,01 & 10,50 & 11,33 & 10,48 & 43,32 \\
Rerata & 2,75 & 2,62 & 2,83 & 2,61 & 2,70 \\
\hline
\end{tabular}

Pada Tabel 3 terlihat bahwa konversi pakan terbaik pada $\mathrm{P}_{3}(2,61)$ diikut $\mathrm{P}_{1}(2,62), \mathrm{P}_{1}(2,75)$ dan terendah $\mathrm{P}_{2}(2,83)$. Hasil analisis variansi menunjukkan bahwa rata-rata konversi pakan berbeda tidak nyata. Peningkatan level probiotik dalam pakan dari 0,3-0,7\% tidak memberikan efek terhadap konversi pakan. Hal ini disebabkan oleh kondisi saluran pencernaan yang sehat dan pakan $\mathrm{BR}_{1}$ dan $\mathrm{BR}_{2}$ yang komplit nutrientnya, menyebabkan pakan yang dikonsumsi dapat dipergunakan semaksimal mungkin untuk ayam broiler. Semakin tinggi konsumsi pakan semakin rendah atau kecil nilai konversi pakan. Nilai suatu ransum selain ditentukan oleh nilai konsumsi ransum dan tingkat pertumbuhan bobot badan juga ditentukan oleh tingkat konversi ransum, dimana konversi ransum menggambarkan banyaknya jumlah ransum yang digunakan untuk pertumbuhan ayam broiler (Wiradisapstra,1986). Sesuai analisis konsumsi pakan dapat dijelaskan bahwa nilai konsumsi pakan meningkat dengan pemberian perlakuan berbeda sangat nyata sehingga nilai konversi pakan semakin baik

\section{Simpulan}

Disimpulkan bahwa penambahan probiotik dalam pakan tidak berpengaruh terhadap pertambahan berat badan, konversi pakan tetapi dapat berpengaruh nyata terhadap konsumsi pakan.

\section{Pustaka}

Ichwan, W. 2004. Membuat Pakan Ayam Ras Pedaging. Agromedia Pustaka: Jakarta

Kartasudjana, R. dan E. Suprijatna. 2006. Manajemen Ternak Unggas. Penebar Swadaya, Jakarta.

Parakkasi, A. 1990. Ilmu Gizi dan Makanan Ternak Monogastrik. Cetakan Pertama. UIP: Jakarta.

Ridho Prasetyo Muhammad. Pengaruh Pemberian Probiotik Untuk Menggantikan Antibiotik Sebagai Growth Promotor Terhadap Performa Ayam Broiler. [Skripsi] ITB: Bandung.

Sumardi. 2008. Seleksi dan karakterisasi mikroflora normal yang prospektif dari saluran pencernaan ayam kampung. http://laptunilapp-gdl-res-2008 sumardidrm-1140. [diakses tanggal 4 Juni 2018].

Soeparno. 2005. Ilmu dan Teknologi Daging. UGM Press, Yogyakarta.

Siregar, A.P. 1980. Teknik Berternak Ayam Pedaging di Indonesia. Merdie Group: Jakarta.

Stell and Torrie. 1991. Prinsip dan Prosedur Statistika Suatu Pendekatan Biometrik.P. T. Gramedia : Jakarta.

Tillman, A.D., H. Hartadi., S. Reksohadiprodjo., S.Prawirokusumo dan S. Lebdosoekojo. 1986. Ilmu Makanan Ternak Dasar. Fak Peternakan. Gajah Mada UniversityPress, Yogyakarta.

Wiradisastra, M.D.H. 1986. Evektivitas Keseimbangan Energi dan Asam Amino dan Efisiensi Absorpsi dalam Menentukan Persyaratan Kecepatan Tumbuh Ayam Broiler. [Disertasi], Institut Pertanian Bogor, Bogor. 